\title{
SPIRITUALITY AND JOB SATISFACTION. MEDIATING ROLE OF STRESS, GRATITUDE TOWARDS ORGANIZATION AND TRUST IN SUPERVISOR. MODERATING ROLE OF RELIGIOUS PRACTICES
}

\begin{abstract}
Spirituality is a relevant factor for employees job satisfaction. The aim of the study was to verify mechanisms of the positive impact of employees spirituality on job satisfaction through the reduction of stress, increased trust in the supervisor and gratitude towards organization. Additional aim was to check moderate role of religious practices measuring frequency of prayer and frequency of of Mass attendance between employees spirituality and job satisfaction. The subjects of conducted research. Were 804 employees from the different organizations. The following measures were used: Employees Spirituality Scale, Gratitude Towards Organization Scale, Trust in Supervisor Scale, Perceived Stress at Work Questionnaire and one item measures regarding job satisfaction, frequency of Mass attendance and frequency of prayer. Gratitude towards organization mediated between spirituality and job satisfaction. Trust in supervisor was a mediator between attitude towards coworkers and job satisfaction. Additionally stress mediated between relationship with God or another "Higher Power" and job satisfaction. Moderating effect of frequency of prayer and frequency of Mass attendance between relationship to God or another "Higher Power" and job satisfaction as well as attitude towards coworkers was confirmed. The important role of employees spirituality for their job satisfaction was confirmed. Recognized mechanisms responsible for indirect positive impact of spirituality on job satisfaction through the gratitude towards organization, trust in supervisor support and stress.
\end{abstract}

Keywords: employees spirituality, gratitude towards organization, trust in supervisor, stress, job satisfaction.

\section{INRODUCTION}

In the last few years there has been an increase interest in employees spirituality research in the context of the function that this sphere of life plays for well-being ${ }^{2}$. There is a lack of

\footnotetext{
${ }^{1}$ Marcin Wnuk, PhD, Adam Mickiewicz University in Poznań, Department of Work and Organizational Psychology, Szamarzewskiego street 89B, 60-568 Poznań, mobile: +48664934268; e-mail: marwnu@ amu.edu.pl. ORCID: 0000-0002-3784-5870.

Dr Marcin Wnuk, Zakład Psychologii Pracy i Organizacji Uniwersytetu im. Adama Mickiewicza, ul. Szamarzewskiego 89B, 60-568 Poznań, tel. +48664934268; e-mail: marwnu@amu.edu.pl. ORCID: 0000-0002-3784-5870.

${ }^{2}$ F. Karakas, Spirituality and performance in organizations: a literature review, "Journal of Business Ethics" 2010, Vol. 94, No. 1, p. 89-106.
} 
research in Poland in this area. In the literature we can recognize mechanisms responsible for influence religious and spiritual facets of life on health, quality of life and well-being ${ }^{3}$. There is a visible deficit of research that would be embedded explaining how in the area of occupational functioning spirituality affects employees well-being. The aim of the study was verification, depiction and explanation of the mechanisms how religious-spiritual activities impact on occupational wellbeing measuring job satisfaction.

Spirituality was verified from a functional point of view in relation to the function that it plays for everyday work ${ }^{4}$ taking into account its individual, not organizational level, concerning the individual experience of each employee in the workplace, regardless of whether the organization supports these experiences and creating conditions for the employees to manifest this sphere of life ${ }^{5}$. The attitude towards God or another "Higher Power" referred to cognitive representation of this phenomenon and the relationship with it based on trust, openness, or a sense of security regardless of whether such a being exist. The attitude towards God was used in the text interchangeably with the relationship with God. Job satisfaction was measured by the general cognitive evaluation of job as a whole.

\section{REVIEW OF LITERATURE}

\subsection{Employees spirituality and religious involvement}

According to Wnuk the employees spirituality consists of two dimensions: a relationship to God or another "Higher Power" and an attitude towards co-workers and organization". The first of them has a religious character and a second one has a secular inclination. God gives the employees a sense of guidance, makes it possible to overcome their limitations, facilitates finding the meaning and purpose at work and is a source of consolation, support and coping. Attitude towards co-workers and organization is defined as a care and concern for the organization interest, counteracting injustices at work, sharing knowledge and experiences, facilitating fulfilling colleagues needs and the ability to appreciate others employees and perceive their dignity as well as a respect ${ }^{7}$.

Among religiously involved employees, this sphere of life is positively connected with the relationship with God. Religious practices are a good opportunity for employees to build and strengthen bonds with God. It means that the religious dimension of spirituality can be shaped by religious practices, while the secular dimension of spirituality is probably not related to religious involvement being affected by non-religious values. Based on this

\footnotetext{
${ }^{3}$ M. Wnuk, J.T. Marcinkowski, Do existential variables mediate between religious-spiritual facets of functionality and psychological wellbeing. "Journal of Religion and Health" 2014, Vol. 53, No. 1, p. 56-67; C.L. Park, Religiousness/Spirituality and health: A meaning systems perspective, "Journal Behavioral Medicine" 2007, Vol. 30, p. 319-328; P. Van Cappellen, M. Toth-Gauthier, V. Saroglou, B.L. Fredrickson, Religion and well-being: The mediating role of positive emotions, "Journal of Happiness Studies" 2015, p. 1-21.

${ }^{4}$ M. Wnuk, The Employee Spirituality Scale as a New Measure of Employees' Spiritual Activity, "Current Psychology" 2018 (in review process).

${ }_{5}^{5}$ R.W. Kolodinsky, R.A. Giacalone, C.L. Jurkiewicz, Workplace values and outcomes: Exploring personal, organizational and interactive workplace spirituality, "Journal of Business Ethics" 2008, Vol. 81, p. 465-480.

${ }^{6} \mathrm{M}$. Wnuk, The Employee Spirituality Scale...

7 Ibidem.
} 
assumption prayer and Mass attendance should be positively correlated with the attitude towards God and not be related to the attitude towards co-workers and organization. According to Zarzycka religious engagement among Poles has no impact on life attitudes, political choices or attitudes towards important worldview values ${ }^{8}$.

Hypothesis 1: Among polish employees religious practices are positively correlated with the relationship with God and there are not related to attitude towards co-workers and organization

The relative independence of both spirituality dimensions can be explained by the employees religious involvement. Religious people have a tendency to identify religiosity with spirituality, using these concepts interchangeably, while for non-religious people who define themselves as spiritual religiosity is something separate from spirituality. It means that one can develop their spirituality outside religious sphere of life ${ }^{9}$. For those who often use religious practices, relationship with God as a religious dimension of spirituality may be a matrix for shaping attitudes towards co-workers and organization, while for those who pray rarely or not at all and do not attend Mass, the religious dimension of spirituality may not be related with its secular factor. Religious practices can be a moderator of the relationship between the two dimensions of employees spirituality.

Also among religious people, involvement in this sphere of life has a positive impact on well-being, but only among nations with a high religiosity indicator. In the studies of Okulicz-Kozaryn and Sabatier et al. conducted among religious societies religiosity was positively related to life satisfaction ${ }^{10}$. Taking into account the fact that according to Zarzycka research Poles are a very religious nation, because only $5 \%$ of the population describes themselves as nonreligious ${ }^{11}$, it should be assumed that the religious dimension of employees spirituality will be positively related to their job satisfaction only among employees with a high level of religious involvement and only in this group of participants will be correlated with an attitude towards co-workers and organization.

Hypothesis 2: Religious practices as a prayer and Mass attendance moderate relationship between relationship with God and attitude towards co-workers and organizations as well as job satisfaction.

\subsection{Spirituality, gratitude and job satisfaction}

Most of recent studies have confirmed that the spiritual and religious sphere of functioning influence on mental and occupational well-being ${ }^{12}$. In the Walker study employees faith was negatively related to the intent to leave the an organization and positively corre-

\footnotetext{
${ }^{8}$ B. Zarzycka, Tradition or Charisma-Religiosity in Poland [In:] Religion Monitor 2008. Europe Overview of Religious Attitudes and Practices, Gütersloh, Bertelsmann Stiftung, 2008, p. 26-29.

9 M. Wnuk, The Employee Spirituality Scale...

10 A. Okulicz-Kozaryn, Religiosity and Life Satisfaction Across Nations, "Mental Health, Religion and Culture" 2010, Vol. 13, No. 2, p. 155-169; C. Sabatier, B. Mayer, M. Friedlmeier, K. Lubiewska, G. Trommsdorff, Religiosity, family orientation, and life satisfaction of adolescents in four countries, "Journal of Cross-Cultural Psychology" 2011, Vol. 42, p. 1375-1393.

11 B. Zarzycka, Tradition or Charisma..., p. 26-29.

${ }^{12}$ F. Karakas, Spirituality and performance..., p. 89-106; M. Wnuk, J.T. Marcinkowski, Do existential variables..., p. 56-67; C.L. Park, Religiousness/Spirituality and health..., p. 319-328.
} 
lated with all three types of organizational commitment ${ }^{13}$. Affeldt and MacDonald confirmed that various aspects of religiosity are positively related to job satisfaction, organizational commitment, work ethics and organizational citizenship behavior ${ }^{14}$. In other studies, the sanctification of work was a significant predictor of job satisfaction, intend to leave an organization and organizational commitment ${ }^{15}$.

In the literature there is a lack of research explaining how the involvement in the spiritual sphere of life affects occupational well-being. There is an evidence that the relations between the employees spirituality and their occupational well-being has an indirect character. Some researchers try to identify the mechanisms of the influence spiritual-religious facets on occupational well-being using mediating variables. For example, among the employees from one of the hospices located in the USA, mediators between the spirituality and job satisfaction were the integration of spirituality at work and self-actualization ${ }^{16}$.

It seems that one of the variables mediating between the spiritual activity of employees and job satisfaction is gratitude towards organization. Gratitude towards organization is a moral attitude consisting of two elements in the form of a generalized conviction that one should be grateful for everything he receives and experiences, the ability to see the good that he has been gifted and emotional reaction appearing in a specific situation of receiving a certain good, accompanied by a commitment and the need to reciprocate motivated by norm of reciprocity ${ }^{17}$.

In the Van Cappellen et al. study gratitude as an emotion mediated in the relationship between spirituality and well-being ${ }^{18}$. In other study gratitude as virtue was a mediator between religiosity and spirituality and well-being because of the ability to forgive and create an altruistic attitude ${ }^{19}$. According to Emmons five factors model of spiritual intelligence consists of ability to engage in virtuous attitudes such as showing forgiveness, expressing gratitude, being humble, showing compassion, and the ability to use spiritual resources to solve problems ${ }^{20}$. In the Manning study one of the three elements of spiritual resilience

13 A.G. Walker, The relationship between the integration of faith and work with life and job outcomes, "Journal of Business Ethics" 2013, Vol. 112, p. 453-461.

${ }^{14}$ D.L. Affeldt, D.A. MacDonald, The relationship of spirituality to work and organizational attitudes and behaviors in a sample of employees from a health care system, "Journal of Transpersonal Psychology" 2010, Vol. 42, No. 2, p. 192-208.

15 S.T. Carroll, J.A. Stewart-Sickingb, B. Thompson, Sanctification of work: assessing the role of spirituality in employment attitudes Stephen, "Mental Health, Religion and Culture" 2014, Vol. 17, No. 6, p. 545-556.

${ }^{16}$ L. Clark, S. Leedy, L. McDonald, B. Muller, C. Lamb, T. Mendez et al., Spirituality and job satisfaction among hospice interdisciplinary team member, "Journal of Palliative Medicine" 2007, Vol. 10, No. 6, p. 1321-1328.

${ }^{17}$ M. Wnuk, Rola managerów dla satysfakcji z pracy pracowników w kontekście wymiany spotecznej, "Ekonomika i Organizacja Przedsiębiorstwa" 2018 (w trakcie recenzji).

${ }^{18}$ P. Van Cappellen, M. Toth-Gauthier, V. Saroglou, B.L. Fredrickson, Religion and well-being..., p. $1-21$.

19 S. Sharma, K. Singh, Religion and well-being: the mediating role of positive virtues, "Journal of Religion and Heatlh" 2018, P. 1-13.

${ }^{20}$ R.A. Emmons, Is spirituality an intelligence? Motivation, cognition, and the psychology of ultimate concern. "The International Journal for the Psychology of Religion" 2000, Vol. 10, No. 1, p. 3-26. 
beyond the support of God and the maintenance of the goal was the expression of gratitude ${ }^{21}$.

Spirituality can influence gratitude towards organization, both through its religious and secular dimension. The relationship with God, as well as the attitude towards co-workers and the organization facilitate employees perceive benefits they receiving both from organization and its representatives as a chance to meet valuable people and build a positive relationship with them, develop professional and personal experiences, or the acquisition of valuable work experiences. Grateful attitude contains a wide range of phenomena, beings, or things such as people, situations, life circumstances, experiences, spiritual resources, internal qualities, future positive experiences, well-being and blessing ${ }^{22}$.

According to Wnuk the source of gratitude towards the organization that leads to greater job satisfaction is interpersonal justice as well as perceived supervisor and organizational support $^{23}$. Employees being convinced that the organization cares about their well-being and their supervisor treats them with kindness and dignity feel gratitude towards the organization, which improve their job satisfaction. Another source of gratitude towards an organization that influence job satisfaction seems to be the employees spirituality. Park has described the mechanisms of the influence of religiosity/spirituality on various aspects of health through the meaning of life, optimism, hope stress and gratitude ${ }^{24}$.

Hypothesis 3: Employees gratitude towards organization mediate between their spirituality, and job satisfaction as well as level of stress.

\subsection{Spirituality, stress and job satisfaction}

From the organization point of view, improving the employees well-being can occur as a result of ensuring a working environment conducive to the expression of spirituality, leading to increased job satisfaction through stress reduction as well as preventing burnout and workaholism. Any employee can use their religious and spiritual inclinations to struggle with everyday problems at work.

Religious people are more likely to use religious coping ${ }^{25}$, and positive references to God improve well-being, while blaming God is connected with reduced quality of life ${ }^{26}$. Relation with God can help employees reduce everyday stress at work by appealing to God in difficult moments, seeking support and consolation on his part or finding meaning and purpose at work.

${ }^{21}$ L.K. Manning, Enduring as lived experience: exploring the essence of spiritual resilience for women in late life, "Journal of Religion and Heatlh" 2014, Vol. 53, p. 352-362.

${ }^{22}$ P.H. Friedman, Creating well-being: The healing path to love, peace, self-esteem and happiness. Saratoga, CA: R and E Publishers 1989.

${ }^{23}$ M. Wnuk, Rola managerów dla satysfakcji..; M. Wnuk, Spostrzegane wsparcie otrzymywane od przełożonego jako istotny czynnik dla satysfakcją z pracy podległych im pracowników - weryfikacja modelu. „Medycyna Pracy” 2018 (w przygotowaniu redakcyjnym).

${ }^{24}$ C.L. Park, Religiousness/Spirituality and health..., p. 319-328.

${ }^{25}$ K.I. Pargament, The psychology of religion and coping, Guilford, New York 1997.

${ }^{26}$ K.I. Pargament, H.G. Koenig, L.M. Perez, The many methods of religious coping: development and initial validation of RCOPE, "Journal of Clinical Psychology" 2000, Vol. 56, No. 4, p. 519-543; K.I. Pargament, N. Tarakeshwar, Ch.G. Ellison, K.M. Wulff, Religious coping among the religious: The relationship between religious coping and well-being in the national sample of presbyterian clergy, elders and members, "Journal for the Scientific Study of Religion" 2001, Vol. 40, No. 3, p. 497-513. 
On the other hand lower level of employees stress contribute to their well-being at work. In the Wnuk study conducted among employees of one large IT organization stress reduction as a result of supervisor support lead to higher job satisfaction ${ }^{27}$.

Stress can also be a mediator between the relationship with God as a source of support in dealing with everyday professional problems and job satisfaction. One of the mechanisms described by Park implies the mediating role of stress between religious and spiritual sphere of functioning and quality of life, indicating on the positive role of religious and spiritual aspects of life for reducing stress, which in turn lead to improve well-being ${ }^{28}$.

Another source of stress reduction may be gratitude towards organization. According to Wnuk gratitude towards organization may reduce stress at work improving indirectly job satisfaction ${ }^{29}$. Wood et al. in their longitudinal studies have shown that gratitude protects against stress and depression ${ }^{30}$.

Hypothesis 4: Stress at work mediate between employees relationship with God and job satisfaction. Another predictor of stress reduction is gratitude towards organization

\subsection{Spirituality, trust in supervisor and job satisfaction}

In the literature we can see lack of research concerning relationship between employees spirituality and trust in supervisor. In the study of Sendjaya and Pekerti conducted on 555 employees from two educational institutions, the management through the service of the leader reflected through morally responsible behaviors had an positive impact on building subordinates trust ${ }^{31}$. In the Kurt et al. study spirituality at work was a predictor of trust ${ }^{32}$, while according to Hassan et al. trust at work is a total mediator between spirituality and job satisfaction ${ }^{33}$. Trust, that is shaped in the relations between the supervisor and the subordinates, in addition to the contextual factors and attributes possessed by the leader, is based on the experiences and personality traits of supervisor ${ }^{34}$.

The key factors necessary to create a trust-based relationship between the supervisor and subordinates is risk taken by the subordinate who may be harm by the supervisor and his potential readiness to hurt, as well as his expectation of appropriate treatment by the supervisor ${ }^{35}$. In this context, subordinates who present a positive attitude towards co-workers and organization which is represented by supervisor ${ }^{36}$ may have a greater propensity to

${ }^{27}$ M. Wnuk, Spostrzegane wsparcie...

${ }^{28}$ C.L. Park, Religiousness/Spirituality and health..., p. 319-328.

${ }^{29}$ M. Wnuk, Spostrzegane wsparcie...

30 A.M. Wood, J.J. Froh, A.W. Geraghty, Gratitude and well-being: A review and theoretical integration, "Clinical Psychology Review" 2010, Vol. 30, p. 890-905.

31 S. Sendjaya, A. Pekerti, Servant leadership as antecedent of trust in organizations, "Leadership \& Organization Development Journal" 2010, Vol. 31, No. 7, p. 643-663.

${ }^{32}$ Y. Kurt, M. Yamin, N. Sinkovic, R.R. Sinkovics, Spirituality as an antecedent of trust and network commitment: the case of anatolian tigers, "European Management Journal" 2016, Vol. 34, No. 6, p. 686-700.

${ }^{33}$ M. Hassan, A.B. Nadeem, A. Akhter, Impact of workplace spirituality on job satisfaction: mediating effect of trust, "Cogent Business \& Management" 2016, Vol. 13, No. 1, p. 1-15.

${ }^{34}$ M. Wnuk, Skala zaufania do przetożonego jako narzędzie do mierzenia zaufania do menadżerów, "Organizacja i Kierowanie" 2018 (w trakcie recenzji).

35 Ibidem.

${ }^{36} \mathrm{H}$. Levinson, Reciprocation: The relationship between man and organization. "Administrative Science Quarterly” 2001, Vol. 9, No. 4, p. 370-390. 
expect a positive attitude of the supervisor towards each other and to display greater tolerance for the risk of potential harm inflicted on their part. It means that employees with a more positive attitude towards co-workers and organization can present a higher level of trust in supervisor.

On the other hand, a positive relationship with supervisor based on trust and perception of support on his part is an important factor for subordinates occupational well-being. Among Australians, the majority of the using measures of trust were positively related to life satisfaction ${ }^{37}$. In the Ward study trust in the team was positively related to satisfaction ${ }^{38}$. Among employees recruited from various organizations located in Poland perceived supervisor support was a positive predictor of subordinates job satisfaction ${ }^{39}$.

Hypothesis 5: Trust in supervisor mediate between attitude towards co-workers and subordinates job satisfaction.

\subsection{Gratitude as a mediating variable between trust in supervisor and subordinates job satisfaction}

The supervisor does not treat all employees in the same way, favoring some at the expense of others ${ }^{40}$. Those who are convinced that their supervisor cares about them and supports them in their activities in accordance with the rule of reciprocity ${ }^{41}$ experience an obligation to repay the organization represented by supervisor ${ }^{42}$, and the result of their gratitude attitude towards organization is their greater job satisfaction ${ }^{43}$. In a sample of employees from one large organization from Poland, gratitude towards organization partially mediated between perceived supervisor support and job satisfaction ${ }^{44}$.

Hypothesis 6: Gratitude towards organization mediate between trust in supervisor and subordinate job satisfaction.

\subsection{Stress at work as a mediating variable between trust in supervisor and job satisfaction}

Relationship with supervisor can be both a source of stress and a way to reduce tension at work. Based on mutual trust, mutual respect and support, it helps to reduce stress at work $^{45}$. Supervisor is the most important source for subordinate support at

\footnotetext{
${ }^{37}$ B. Tranter, Z. Skrbis, Interpersonal trust, institutional trust and confidence in significant others among young Queenslanders, "Australian Journal of Political Science" 2009, Vol. 44, No. 4, p. 659-678.

38 E. Ward, Autonomous work groups: A field study of correlates of satisfaction, "Psychological Reports" 1997, Vol. 80, p. 60-62.

${ }^{39}$ M. Wnuk, Spostrzegane wsparcie...

${ }^{40}$ D.T. Hooper, R. Martin, Beyond personal leader.member-exchange (LMX) quality: The effects of perceived LMX variability on employee reactions, "The Leadership Quarterly" 2008, Vol.19, p. $20-30$.

41 A.W. Gouldner, The norm of reciprocity: A preliminary statement. "American Sociological Review" 1960, Vol 25, No. 2, p. 161-178.

${ }^{42}$ H. Levinson, Reciprocation..., p. 370-390.

${ }^{43}$ M. Wnuk, Rola managerów dla satysfakcji...; M. Wnuk, Spostrzegane wsparcie...

${ }^{44}$ M. Wnuk, Spostrzegane wsparcie...

${ }^{45}$ Ibidem.
} 
work $^{46}$, contributing to effective coping with subordinate stress by providing emotional and instrumental support, creative management of the professional and family spheres, or presenting attitudes in the role modeling ${ }^{47}$.

Employees who experience low level of supervisor support in comparison to employees with high level of supervisor support more stressed at work. According to Wnuk perceived supervisor support reduce the level of stress indirectly leading to higher job satisfaction ${ }^{48}$.

Also, trust in supervisor, being a separate, although similar construct from the perceived supervisor support ${ }^{49}$ may reduce the employees level of stress leading indirectly to improve job satisfaction. Trust in supervisor because of his integrity, openness to the employee's needs, not abusing power, keeping promises or creating a sense of stability and predictability in the workplace may contribute to a lower level of stress, which in turn lead to higher level of job satisfaction.

Hypothesis 7: Stress at work mediate between trust in supervisor and subordinates job satisfaction

\section{MATERIAL AND METHODS}

\subsection{Participants research}

The study was conducted on 804 employees from the different organizations located in Poland. The survey was anonymous. All participants agreed to take part in the study. In the study sample, $41,9 \%$ participants were men and 58,1\% were women. The mean work seniority was 7,14 years $(\mathrm{SD}=9,36)$, whereas the mean work seniority in the current workplace was 3,97 years $(\mathrm{SD}=6,59)$. The mean age was 28,08 years $(\mathrm{SD}=10,24)$.

\subsection{Research tools}

Employees spirituality was verified by Employees Spirituality Scale ${ }^{50}$. Participants respond on a 5-point Likert scale ranging from $1=$ strongly disagree to $5=$ strongly agree . The reliability of the scale using $\alpha$-Cronbach coefficient was 0,94 .

Trust in supervisor was measured by Trust in Supervisor Scale ${ }^{51}$. This tool consists of two factors: benevolence and integrity as well as abilities. Each question is rated on a 5-point Likert scale ranging from $1=$ strongly disagree to $5=$ strongly agree. The reliability of the scale in measuring the $\alpha$-Cronbach coefficient was 0,94 .

\footnotetext{
${ }^{46}$ M. Frese, Social support as a moderator of the relationship between work stressors and psychological dysfunctioning. "Journal of Occupational Health Psychology" 1999, Vol 4, No. 3, p. 179-192.

47 L. Hammer, E. Kossek, N. Yragui, T. Bodner, G. Hanson, Development and validation of a multidimensional scale of family-supportive supervisor behaviors (FSSB), "Journal of Management" 2009, Vol. 35, p. 837-856.

${ }^{48}$ M. Wnuk, Spostrzegane wsparcie...

${ }^{49}$ M. Wnuk, Skala zaufania do przełożonego...

${ }^{50}$ M. Wnuk, The Employee Spirituality Scale...

${ }^{51}$ M. Wnuk, Skala zaufania do przełożonego...
} 
Grattitude towards organization was tested by Grattitude Towards Organization Scale ${ }^{52}$. In the study used four from eight sentences regarding gratitude as a commitment to reciprocity. Each question is rated on a 5-point Likert scale ranging from $1=$ strongly disagree to $5=$ strongly agree. The reliability of the scale was $\alpha$-Cronbach $=0,87$.

Job satisfaction was measured using one statement „Generally I like work here”. Participants responded on a 7-point Likert scale ranging from $1=$ strongly disagree to 5 = strongly agree.

Stress at work was measured using Perceived Stress at Work ${ }^{53}$. Participants respond on a 5-point Likert scale ranging from $5=$ never to $1=$ almost always. In the study used five from ten questions strongest loading this measure. The reliability of this tool was $\alpha$-Cronbacha $=0,89$.

Religious involvement was measured by frequency of religious practices. Participants responded for questions regarding frequency of prayer and Mass attendance. In the literature those measures are very often using as a indicators of religious engagement.

\section{RESULTS}

Descriptives statistics were presented in table 1.

Table 1. Descriptive statistics $(\mathrm{N}=804)$

\begin{tabular}{|l|c|c|c|c|c|c|c|}
\hline & $\mathrm{N}$ & Minimum & Maximum & Mean & $\begin{array}{c}\text { Standard } \\
\text { deviation }\end{array}$ & Skewness & Kurtosis \\
\hline $\begin{array}{l}\text { Relationship with } \\
\text { God }\end{array}$ & 804 & 12,00 & 60,00 & 31,33 & 13,77 & 0,38 & $-1,10$ \\
\hline $\begin{array}{l}\text { Attitude towards } \\
\text { co-workers }\end{array}$ & 804 & 12,00 & 60,00 & 49,81 & 5,96 & $-1,11$ & $-1,08$ \\
\hline $\begin{array}{l}\text { Frequency of } \\
\text { Mass attendance }\end{array}$ & 804 & 1,00 & 5,00 & 2,54 & 1,52 & 0,53 & $-1,25$ \\
\hline $\begin{array}{l}\text { Frequency of } \\
\text { prayer }\end{array}$ & 804 & 1,00 & 5,00 & 2,48 & 1,53 & 0,66 & $-1,12$ \\
\hline $\begin{array}{l}\text { Gratitude towards } \\
\text { organization }\end{array}$ & 804 & 4,00 & 20,00 & 13,77 & 3,37 & $-0,33$ & $-0,04$ \\
\hline Trust in supervisor & 804 & 22,00 & 100,00 & 71,89 & 14,66 & $-0,59$ & 0,58 \\
\hline Stress at work & 804 & 5,00 & 25,00 & 13,11 & 4,38 & 0,35 & $-0,10$ \\
\hline Job satisfaction & 804 & 1,00 & 7,00 & 5,01 & 1,45 & $-0,64$ & $-0,04$ \\
\hline
\end{tabular}

(source: own preparation)

The model fit was verified by structural equation modeling using maximum likelihood method. Tested model was presented at scheme 1 .

${ }^{52}$ M. Wnuk, Wdzięczność wobec organizacji jako nowy konstrukt w psychologii pracy. Właściwości psychometryczne Skali Wdzięczności wobec Organizacji, referat przygotowany na 36. Kongres Polskiego Towarzystwa Psychologicznego „Psychologia dla zdrowia osoby i społeczeństwa”, 21-24 września 2017 r., Gdańsk.

${ }^{53}$ T. Chirkowska-Smolak, J. Grobelny, Konstrukcja i wstępna analiza psychometryczna Kwestionariusza Postrzeganego Stresu w Pracy (PSwP), „Czasopismo Psychologiczne” 2016, t. 22, nr 1, s. 131-139. 


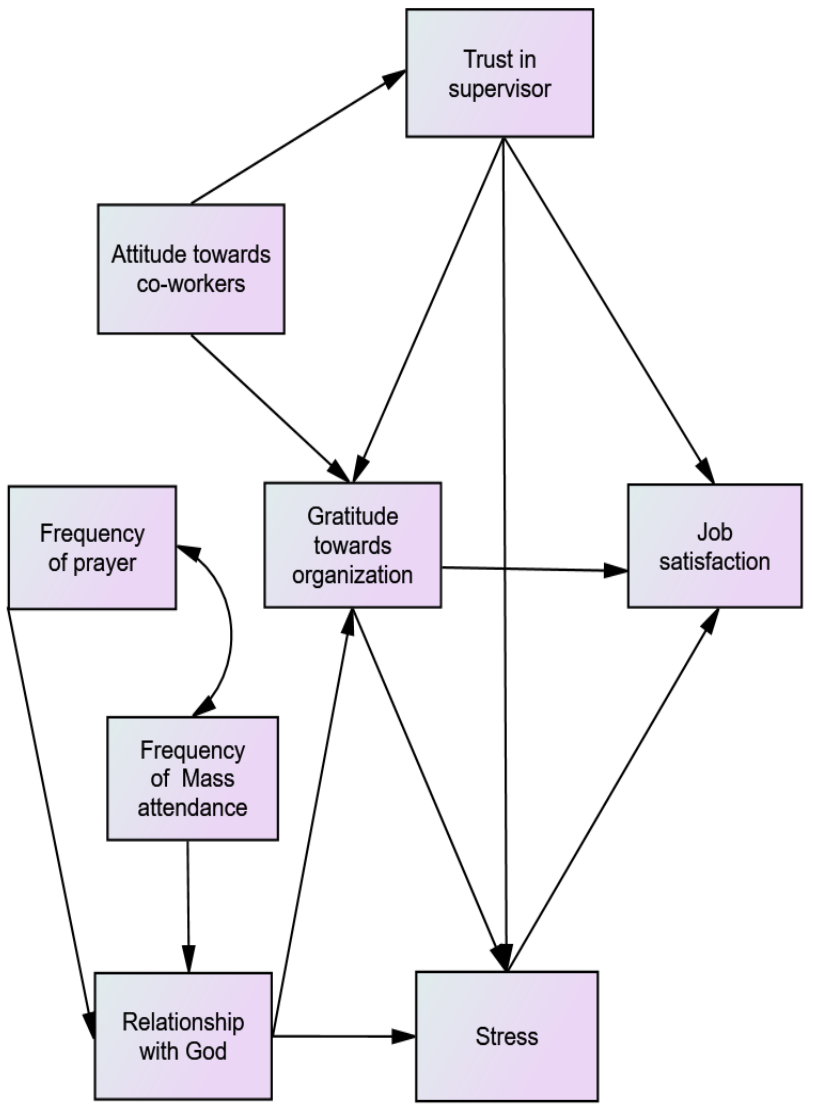

Scheme 1. Model reflecting research hypotheses $(\mathrm{N}=804)$

Source: own preparation.

The following fit model indicators were used: Normed Fit Index - NFI, Goodness of Fit Index - GFI, Comparative Fit Index-CFI, Root Mean Square Error of Approximation - RMSEA. The value of RMSEA indicator $[0,020,90 \%(0,000 ; 0,041)]$, was below 0,05 level, which was a proof of ideal model fit ${ }^{54}$. Also values of NFI $(0,99)$, GFI $(0,99)$ and CFI $(0,99)$ indicators were higher than references values amounting respectively 0,90 , 0,90 and $0,93^{55}$. The value of CMIN / DF statistics based on chi-square statistics $-1,324$ $(\mathrm{p}=0,177)$ was lower than standard -2 or $3^{56}$.

${ }^{54}$ J.H. Steiger, Structural model evaluation and modification: An interval estimation approach, "Multivariate Behavioral Research" 1990, Vol. 25, No. 2, p. 173-180.

${ }_{55}$ B.M. Byrne, Structural equation modeling with EQS and EQS/Windows, SAGE Publications, Thousand Oaks 1994.

${ }^{56}$ R.B. Kline, Principles and practice of structural equation modeling, Guilford Press, New York 1998. 
The results of models reflecting moderating role of religious practices were presented in table 2. In model 1 presented results of frequency of prayer moderating effect between relationship with God and attitude towards co-workers and organizations. In model 2 presented results frequency of prayer moderating effect between relationship with job satisfaction. In model 3 presented results of frequency of Mass attendance moderating effect between relationship with God and attitude towards co-workers and organizations In model 4 presented results of frequency of Mass attendance moderating effect between relationship with God and job satisfaction.

Table 2. Results of verification frequency of prayer and Mass attendance as a moderating variable between relationship with God and attitude towards co-workers and organization as well as a job satisfaction $(\mathrm{N}=804)$

\begin{tabular}{|c|c|c|c|}
\hline $\begin{array}{c}\text { Number of } \\
\text { model }\end{array}$ & $\begin{array}{c}\text { F-Statistic for model with } \\
\text { interactive variable }\end{array}$ & $\begin{array}{c}\text { Change } \mathrm{R} \\
\text { square }\end{array}$ & Beta for interactive variable \\
\hline Model 1 & $\mathrm{F}=10,85$ & $0,013^{* *}$ & $0,397 * *$ \\
\hline Model 2 & $\mathrm{F}=6,21$ & $0,008^{*}$ & $0,302^{*}$ \\
\hline Model 3 & $\mathrm{F}=6,30$ & $0,008^{*}$ & $0,303^{*}$ \\
\hline Model 4 & $\mathrm{F}=7,98$ & $0,010^{* *}$ & $0,327 * *$ \\
\hline
\end{tabular}

$* \mathrm{p} \leq 0,05$

$* * \mathrm{p} \leq 0,01$

Source: own preparation.

According to results both prayer and Mass attendance were moderators between relationship with God and attitude towards co-workers as well as job satisfaction.

Further analyzes have shown that, as expected relationship with God has a positive effect on attitude towards co-workers and organization only among very religious employees, those who attend Mass once a week or more (beta $=0,244 ; \mathrm{p} \leq 0.01$ ). Also among this group of participants relationship with God positively predicted job satisfaction (beta $=0,167$; $\mathrm{p} \leq 0,05)$, while among employees never attend Mass this variable negatively predicted job satisfaction (beta $=-0,141 ; \mathrm{p} \leq 0,05$ ).

In the sample of employees who attend Mass less frequently or not at all relationship with God was not related to attitude towards co-workers and organization. For employees praying every day relationship with God was positively correlated with attitude towards coworkers and organization (beta $=0,278 ; \mathrm{p} \leq 0,01$ ) as well as job satisfaction (beta=0,172; $\mathrm{p} \leq 0,05)$.

In tables 3, 4, 5 were shown total effect, direct effect and indirect effect the mutual influence of the variables. 
Table 3. Standarized total effect $(\mathrm{N}=804)$

\begin{tabular}{|l|c|c|c|c|c|c|c|}
\hline & Prayer & $\begin{array}{c}\text { Mass } \\
\text { Attendance }\end{array}$ & $\begin{array}{c}\text { Attitude } \\
\text { towards } \\
\text { co-workers }\end{array}$ & $\begin{array}{c}\text { Trust in } \\
\text { supervisor }\end{array}$ & $\begin{array}{c}\text { Relationship } \\
\text { with God }\end{array}$ & $\begin{array}{c}\text { Gratitude } \\
\text { towards } \\
\text { organization }\end{array}$ & Stress \\
\hline $\begin{array}{l}\text { Trust in } \\
\text { supervisor }\end{array}$ & 0,00 & 0,00 & 0,37 & 0,00 & 0,00 & 0,00 & 0,00 \\
\hline $\begin{array}{l}\text { Relationship } \\
\text { with God }\end{array}$ & 0,40 & 0,41 & 0,00 & 0,00 & 0,00 & 0,00 & 0,00 \\
\hline $\begin{array}{l}\text { Gratitude } \\
\text { toward } \\
\text { organization }\end{array}$ & 0,05 & 0,05 & 0,29 & 0,55 & 0,11 & 0,00 & 0,00 \\
\hline Stress & 0,03 & 0,03 & $-0,19$ & $-0,45$ & 0,06 & $-0,21$ & 0,00 \\
\hline $\begin{array}{l}\text { Job } \\
\text { satisfaction }\end{array}$ & 0,02 & 0,02 & 0,22 & 0,48 & 0,04 & 0,48 & 0,19 \\
\hline
\end{tabular}

Source: own preparation.

Table 4. Standarized direct effect $(\mathrm{N}=804)$

\begin{tabular}{|l|c|c|c|c|c|c|c|}
\hline & Prayer & $\begin{array}{c}\text { Mass } \\
\text { Attendance }\end{array}$ & $\begin{array}{c}\text { Attitude } \\
\text { towards } \\
\text { co-workers }\end{array}$ & $\begin{array}{c}\text { Trust in } \\
\text { supervisor }\end{array}$ & $\begin{array}{c}\text { Relationship } \\
\text { with God }\end{array}$ & $\begin{array}{c}\text { Gratitude } \\
\text { towards } \\
\text { organization }\end{array}$ & Stress \\
\hline $\begin{array}{l}\text { Trust in } \\
\text { supervisor }\end{array}$ & 0,00 & 0,00 & 0,37 & 0,00 & 0,00 & 0,00 & 0,00 \\
\hline $\begin{array}{l}\text { Relationship } \\
\text { with God }\end{array}$ & 0,40 & 0,41 & 0,00 & 0,00 & 0,00 & 0,00 & 0,00 \\
\hline $\begin{array}{l}\text { Gratitude } \\
\text { toward } \\
\text { organization }\end{array}$ & 0,00 & 0,00 & 0,09 & 0,55 & 0,12 & 0,00 & 0,00 \\
\hline Stress & 0,00 & 0,00 & 0,00 & $-0,33$ & 0,09 & $-0,21$ & 0,00 \\
\hline $\begin{array}{l}\text { Job } \\
\text { satisfaction }\end{array}$ & 0,00 & 0,00 & 0,00 & 0,15 & 0,00 & 0,44 & $-0,19$ \\
\hline
\end{tabular}

Source: own preparation.

Table 5. Standarized indirect effect $(\mathrm{N}=804)$

\begin{tabular}{|l|c|c|c|c|c|c|c|}
\hline & Prayer & $\begin{array}{c}\text { Mass } \\
\text { Attendance }\end{array}$ & $\begin{array}{c}\text { Attitude } \\
\text { towards } \\
\text { co-workers }\end{array}$ & $\begin{array}{c}\text { Trust in } \\
\text { supervisor }\end{array}$ & $\begin{array}{c}\text { Relationship } \\
\text { with God }\end{array}$ & $\begin{array}{c}\text { Gratitude } \\
\text { towards } \\
\text { organization }\end{array}$ & Stress \\
\hline $\begin{array}{l}\text { Trust in } \\
\text { supervisor }\end{array}$ & 0,00 & 0,00 & 0,00 & 0,00 & 0,00 & 0,00 & 0,00 \\
\hline $\begin{array}{l}\text { Relationship } \\
\text { with God }\end{array}$ & 0,00 & 0,00 & 0,00 & 0,00 & 0,00 & 0,00 & 0,00 \\
\hline $\begin{array}{l}\text { Gratitude } \\
\text { toward } \\
\text { organization }\end{array}$ & 0,05 & 0,05 & 0,20 & 0,00 & 0,00 & 0,00 & 0,00 \\
\hline Stress & 0,03 & 0,03 & $-0,19$ & $-0,12$ & $-0,03$ & 0,00 & 0,00 \\
\hline $\begin{array}{l}\text { Job } \\
\text { satisfaction }\end{array}$ & 0,02 & 0,02 & 0,22 & 0,33 & 0,04 & 0,04 & 0,00 \\
\hline
\end{tabular}

Source: own preparation. 


\section{DISCUSSION}

The obtained results have confirmed the first hypothesis stating that among religious involvement employees antecedent of positive relationship with God are religious practices, such as prayer and Mass attendance, which in turn are not related to the second, secular dimension of employees spirituality as an attitude towards co-workers and organization. As supposed among polish employees due to their religious affiliation and the fact that very large percentage of people believe in God, "Higher Power" is identified with God.

The same as in Zarzycka research religious practices were not related to a positive attitude towards important life issues, as an attitude towards co-workers and organization ${ }^{57}$.

The second hypothesis was confirmed. Prayer and Mass attendance were moderators between attitude towards God and the attitude towards co-workers and organization, as well as job satisfaction. Among religious involvement employees noticed beneficiary effect influence religious practices on attitude towards co-workers and organization as well as job satisfaction. No statistical effect has revealed in a group of employees non-religious involvement, with one exception regarding detrimental effect of Mass attendance on job satisfaction among employees never attend Mass.

It means that in group of non-religious involvement employees the source of the positive attitude towards co-workers and organization are other secular values internalized in socialization process, shaping their moral principles, as well as the perceived image of the world, themselves and other people. These values are the base for the acceptance of colleagues at work, understanding of them, noticing their efforts at work, caring for their needs or sharing with them knowledge and experiences. In group of religious involvement employees antecedent of positive attitude towards colleagues and organization being a matrix for treating other people properly is relationship with God. The obtained results are consistent with results of research conducted by Okulicz-Kozaryn ${ }^{58}$ according to which religious involvement is positively related to well-being only among societies with a high religiousness rate, to which Poland can undoubtedly be included.

The third hypothesis regarding gratitude towards organization as a mediator between spirituality and job satisfaction has been fully confirmed. It turned out that both religious and secular dimension of employees spirituality is a source of gratitude towards organization, indirectly improving job satisfaction. These results are in the line with recent research indicating that apart from the perceived supervisor and organizational support, stress at work and work-life balance ${ }^{59}$ another factor influence on gratitude towards organization, indirectly improving job satisfaction is spirituality. Above mechanism can be explained by the schematic hypothesis according to which employees presenting a higher level of gratitude because they perceive support and help from other people as more altruistic, more costly and more valuable ${ }^{60}$. Spirituality aspects of life which they develop in their relationships with God, their co-workers and the organization strengthens their sense of gratitude, leading finally to greater job satisfaction.

Partially confirmed third hypothesis about employees stress at work as a mediator between relationship with God and job satisfaction. Relationship with God was a positive

\footnotetext{
${ }^{57}$ B. Zarzycka, Tradition or Charisma-Religiosity..., p. 26-29.

${ }^{58}$ A. Okulicz-Kozaryn, Religiosity and Life Satisfaction..., p. 155-169.

${ }^{59}$ M. Wnuk, Rola managerów...; M. Wnuk, Spostrzegane wsparcie...

${ }^{60}$ A.M. Wood, J. Maltby, R. Gillett, P.A. Linley, S. Joseph, The role of gratitude..., p. 854-871.
} 
predictor of employees stress at work, but it was rather a proof that employees being under the stress try to reduce it by referring to relationships with God and looking for his support than that the relationship with God is a source of stress at work. The confirmation of this assumption is fact that the attitude towards God also indirectly reduce stress at work through gratitude towards organization ${ }^{61}$. People who declare a high level of gratitude effectively use such methods of coping with stress, less frequent self-blame and more often using positive reinterpretations and growth, which together explain $51 \%$ variance between gratitude and stress ${ }^{62}$.

Achieving results are partially consistent with recent research proving that another antecedent of stress coping at work beside of perceived supervisor support ${ }^{63}$ is relationship with God.

According to Pargament ${ }^{64}$ and Pargament et al ${ }^{65}$ positive references to God can be an effective method of coping with stress also on the professional ground. God can be a source of consolation at work, support of employees in everyday duties, coping with difficult times etc., leading to gratitude towards organization and indirectly reducing the level of stress at work.

Consistent with hypothesis fifth trust in supervisor mediated between the attitude towards co-workers as well as organization and job satisfaction. It means that caring for the needs of colleagues, respect and understanding for them, sharing knowledge and experiences, and caring for the organization interests have positive impact on trust in supervisor indirectly improving job satisfaction. The more positive attitude towards co-workers and organization are presented by employees, the more they trust in supervisors, which in turn improve their job satisfaction. It means that the relationship of mutual trust between subordinate and supervisor, as well as perceived supervisor support ${ }^{66}$ can positively affect job satisfaction. Concluding, basis for building employees trust in supervisors is their own positive attitude towards co-workers and organization being a manifestation of their spiritual activity in the sphere of occupational functioning.

Hypothesis six about gratitude towards organization as a partial mediator between trust in supervisor and job satisfaction was fully confirmed. Trust in supervisor who can be seen by subordinate as a personification of organization ${ }^{67}$, reflecting the quality of relationship between subordinate and supervisor, according to reciprocity norm ${ }^{68}$ through gratitude motivate him to repay organization finally improving his job satisfaction. The obtained results are consistent with Wnuk research conducted on employees of one large organization from Poland, where perceived supervisor support indirectly influenced on job satisfaction through gratitude towards organization ${ }^{69}$. The supervisor positive attitude towards subordinate may strengthen the subordinate conviction that supervisor activities towards him are

\footnotetext{
${ }^{61}$ M. Wnuk, Spostrzegane wsparcie...

${ }^{62}$ A.M. Wood, J. Maltby, R. Gillett, P.A. Linley, S. Joseph, The role of gratitude..., p. 854-871.

${ }^{63}$ M. Wnuk, Skala zaufania do przetożonego...

${ }^{64}$ K.I. Pargament, The psychology of religion...

${ }^{65}$ K.I. Pargament, H.G. Koenig, L.M. Perez, The many methods..., p. 519-543.

${ }^{66}$ M. Wnuk, Spostrzegane wsparcie...

${ }^{67}$ H. Levinson, Reciprocation..., p. 370-390.

${ }^{68}$ A.W. Gouldner, The norm of reciprocity..., p. 161-178.

${ }^{69}$ M. Wnuk, Spostrzegane wsparcie...
} 
more altruistic, more expensive and more valuable leading to improve his job satisfaction ${ }^{70}$. One of the dimensions of trust in supervisor is benevolence and integrity manifested in supervisor behavior through openness and selflessness in relation with his subordinate ${ }^{71}$.

Also hypothesis seven regarding stress at work as a partial mediator between trust in supervisor and job satisfaction was fully confirmed. For employees, a relationship with a supervisor based on trusting him as a leader who treats them equally, is honest, keeps promises and does not abuse the power reduces subordinates symptoms of stress, which in turn has a positive impact on their job satisfaction. These results are consistent with previous research, according to which perceived supervisor support influenced on job satisfaction both directly and indirectly by reducing stress ${ }^{72}$.

\section{CONCLUSIONS}

Conducted research has some theoretical and practical implications. It was confirmed that employees religious practices are not related to secular dimension of spirituality as an attitude towards co-workers and organization and moderate attitude towards God and attitude towards co-workers and organization as well as job satisfaction. Among religious involvement employees relationship with God is positively related to attitude towards coworkers and organization as well as job satisfaction.

Three mechanisms of indirect impact of employees spirituality on their occupational well-being measured by job satisfaction were discovered and confirmed. Employees spirituality is antecedent of gratitude towards organization, which in turn lead to their higher job satisfaction.

Relationship with God has a positive direct impact on job satisfaction and negative indirect influence on this variable through the stress at work.

Employees attitude towards co-workers and organization positive increases their trust in supervisor, which results in their greater job satisfaction.

In heterogeneous group of employees from different organizations confirmed that the relationship with supervisor using trust in supervisor measure affects job satisfaction both directly and indirectly through gratitude towards organization and stress at work. The obtained results are consistent with previous study conducted among employees from one large organization where perceived supervisor support indirectly improved job satisfaction through gratitude towards organization and stress at work $^{73}$.

The practical implications of the conducted research concern building among human resources managers and specialist awareness of the important role of spirituality for the functioning of employees in the workplace and their well-being. They should not limit or prevent the expression of the spiritual sphere of employees, respecting and accepting manifestations of spirituality and religiosity at work. From the recruitment point of view organizations should employ candidates for whom the spiritual sphere plays an important role in everyday life, because at work in dealing with professional problems they will be able to use an additional source of support and coping with stress in the form of a relationship with

70 A.M. Wood, J.J. Froh, A.W. Geraghty, Gratitude and well-being: A review and theoretical integration, "Clinical Psychology Review" 2010, Vol. 30, p. 890-905.

${ }^{71}$ M. Wnuk, Skala zaufania do przełożonego...

${ }^{72}$ M. Wnuk, Spostrzegane wsparcie...

73 Ibidem. 
God or another "Higher Power". In addition, they will be more grateful to the organization, able to appreciate what they receive from it, and it will be easier for them to build relationships with their supervisors based on trust.

The conducted study has some limitations. First of all only one indicator of occupational well-being was used. The obtained results can be generalized only rather to young employees of organizations located in Poland, which means that they can be considered only in a specific cultural and social context. Achieving results should not be generalized for representatives of every denominations because of a lack of a question concerning religious affiliation.

Future research concerning relationship between employees spirituality and their occupational wellbeing should be conducted in a different cultural context to verify if obtained results have a universal character.

Additional recommendation is using other occupational wellbeing indicators in the form of organizational attachment or intention to quit organization as well as verifying other potential mediators between employees spirituality and occupational wellbeing such as meaning and purpose at work, hope, forgiveness or positive affect.

\section{REFERENCES}

1. Affeldt D.L., MacDonald D.A., The relationship of spirituality to work and organizational attitudes and behaviors in a sample of employees from a health care system, "Journal of Transpersonal Psychology” 2010, Vol. 42, No. 2.

2. Byrne B.M., Structural equation modeling with EQS and EQS/Windows, SAGE Publications, Thousand Oaks 1994.

3. Carroll S.T., Stewart-Sickingb J.A., Thompson B., Sanctification of work: assessing the role of spirituality in employment attitudes Stephen, "Mental Health, Religion and Culture" 2014, Vol. 17, No. 6.

4. Chirkowska-Smolak T., Grobelny J., Konstrukcja i wstępna analiza psychometryczna Kwestionariusza Postrzeganego Stresu w Pracy (PSwP), „Czasopismo Psychologiczne” 2016, t. $22, \mathrm{nr} 1$.

5. Clark L., Leedy S., McDonald L., Muller B., Lamb C., Mendez T. et al., Spirituality and job satisfaction among hospice interdisciplinary team member, "Journal of Palliative Medicine" 2007, Vol. 10, No. 6.

6. Emmons R.A., Is spirituality an intelligence? Motivation, cognition, and the psychology of ultimate concern, "The International Journal for the Psychology of Religion" 2000, Vol. 10, No. 1.

7. Frese M., Social support as a moderator of the relationship between work stressors and psychological dysfunctioning, "Journal of Occupational Health Psychology" 1999, Vol 4, No. 3.

8. Friedman P.H., Creating well-being: The healing path to love, peace, self-esteem and happiness. Saratoga, CA: R and E Publishers 1989.

9. Gouldner A.W., The norm of reciprocity: A preliminary statement, "American Sociological Review" 1960, Vol. 25, No. 2.

10. Hammer L., Kossek E., Yragui N., Bodner T., Hanson G., Development and validation of a multidimensional scale of family-supportive supervisor behaviors (FSSB), "Journal of Management" 2009, Vol. 35. 
11. Hassan M., Nadeem A.B., Akhter A., Impact of workplace spirituality on job satisfaction: mediating effect of trust, "Cogent Business \& Management" 2016, Vol. 13, No. 1.

12. Hooper D.T., Martin R., Beyond personal leader.member-exchange (LMX) quality: The effects of perceived LMX variability on employee reactions, "The Leadership Quarterly" 2008, Vol. 19.

13. Karakas F., Spirituality and performance in organizations: a literature review, "Journal of Business Ethics" 2010, Vol. 94, No. 1.

14. Kline R.B., Principles and practice of structural equation modeling, Guilford Press, New York 1998.

15. Kolodinsky R.W., Giacalone R.A., Jurkiewicz C.L., Workplace values and outcomes: Exploring personal, organizational and interactive workplace spirituality, "Journal of Business Ethics" 2008, Vol. 81.

16. Kurt Y., Yamin M., Sinkovic N., Sinkovics R.R., Spirituality as an antecedent of trust and network commitment: the case of anatolian tigers, "European Management Journal" 2016, Vol. 34, No. 6.

17. Levinson H., Reciprocation: The relationship between man and organization. "Administrative Science Quarterly" 2001, Vol. 9, No. 4.

18. Manning L.K., Enduring as lived experience: exploring the essence of spiritual resilience for women in late life, "Journal of Religion and Heatlh" 2014, Vol. 53.

19. Okulicz-Kozaryn A., Religiosity and Life Satisfaction Across Nations, "Mental Health, Religion and Culture" 2010, Vol. 13, No. 2.

20. Pargament K.I., Koenig H.G., Perez L.M., The many methods of religious coping: development and initial validation of RCOPE, "Journal of Clinical Psychology" 2000, Vol. 56, No. 4.

21. Pargament K.I., Tarakeshwar N., Ellison Ch.G., Wulff K.M., Religious coping among the religious: The relationship between religious coping and well-being in the national sample of presbyterian clergy, elders and members, "Journal for the Scientific Study of Religion" 2001, Vol. 40, No. 3.

22. Pargament K.I., The psychology of religion and coping, Guilford, New York 1997.

23. Park C.L., Religiousness/Spirituality and health: A meaning systems perspective, "Journal Behavioral Medicine", 2007, Vol. 30.

24. Sabatier C., Mayer B., Friedlmeier M., Lubiewska K., Trommsdorff G., Religiosity, family orientation, and life satisfaction of adolescents in four countries, "Journal of Cross-Cultural Psychology" 2001, Vol. 42.

25. Sendjaya S., Pekerti A., Servant leadership as antecedent of trust in organizations, "Leadership \& Organization Development Journal" 2010, Vol. 31, No. 7.

26. Sharma S., Singh K., Religion and well-being: the mediating role of positive virtues, "Journal of Religion and Heatlh" 2018.

27. Steiger J.H., Structural model evaluation and modification: An interval estimation approach, "Multivariate Behavioral Research" 1990, 25(2).

28. Tranter B., Skrbis Z. Interpersonal trust, institutional trust and confidence in significant others among young Queenslanders, "Australian Journal of Political Science" 2009, Vol. 44, No. 4.

29. Van Cappellen P., Toth-Gauthier M., Saroglou V., Fredrickson, B.L., Religion and wellbeing: The mediating role of positive emotions, "Journal of Happiness Studies” 2015. 
30. Walker A.G., The relationship between the integration of faith and work with life and job outcomes, "Journal of Business Ethics" 2013, Vol. 112.

31. Ward E., Autonomous work groups: A field study of correlates of satisfaction, "Psychological Reports" 1997, Vol. 80.

32. Wnuk M., Wdzięczność wobec organizacji jako nowy konstrukt w psychologii pracy. Wtaściwości psychometryczne Skali Wdzięczności wobec Organizacji, referat przygotowany na 36. Kongres Polskiego Towarzystwa Psychologicznego „Psychologia dla zdrowia osoby i społeczeństwa", 21-24 września 2017 r., Gdańsk.

33. Wnuk M., The Employee Spirituality Scale as a New Measure of Employees' Spiritual Activity, "Current Psychology" 2018 (w trakcie recenzji).

34. Wnuk M., Rola managerów dla satysfakcji z pracy pracowników w kontekście wymiany społecznej, „Ekonomika i Organizacja Przedsiębiorstwa” 2018 (w trakcie recenzji).

35. Wnuk M., Spostrzegane wsparcie otrzymywane od przetożonego jako istotny czynnik dla satysfakcji z pracy podległych im pracowników - weryfikacja modelu, „Medycyna Pracy” 2018 (w przygotowaniu redakcyjnym).

36. Wnuk M., Skala zaufania do przełożonego jako narzędzie do mierzenia zaufania do menadżerów, „Organizacja i Kierowanie” 2018 (w trakcie recenzji).

37. Wnuk M., Marcinkowski J.T., Do existential variables mediate between religious-spiritual facets of functionality and psychological wellbeing, "Journal of Religion and Health" 2014, Vol. 53, No. 1.

38. Wood A.M., Froh J.J., Geraghty A.W., Gratitude and well-being: A review and theoretical integration, "Clinical Psychology Review" 2010, Vol. 30.

39. Wood A.M., Maltby J., Gillett R., Linley P.A., Joseph S., The role of gratitude in the development of social support, stress, and depression: Two longitudinal studies, "Journal of Research in Personality” 2008, Vol. 42.

\section{INTERNET SOURCES}

1. Zarzycka B., Tradition or Charisma-Religiosity in Poland [In:] Religion Monitor 2008. Europe Overview of Religious Attitudes and Practices, Gütersloh, Bertelsmann Stiftung, 2008, http://www.bertelsmann-stiftung.de/cps/rde/xbcr/SID-8D335224-48508547/bst/Religions Monitor_Europa_engl.pdf.

\section{DUCHOWOŚĆ A SATYSFAKCJA Z PRACY. MEDIACYJNA ROLA STRESU, WDZIECZNOŚCI WOBEC ORGANIZACJI ORAZ ZAUFANIA DO PRZELOŻONEGO. MODERACYJNA ROLA PRAKTYK RELIGIJNYCH}

Duchowość pracowników jest istotnym czynnikiem kształtującym satysfakcję z pracy. Celem przeprowadzonych badań była weryfikacja mechanizmów wpływu duchowości pracowników na ich satysfakcję z pracy za pośrednictwem redukcji doświadczanego stresu, wzrostu zaufania do przełożonego oraz wdzięczności wobec organizacji. Dodatkowym celem było sprawdzenie moderacyjnej roli praktyk religijnych, takich jak częstotliwość modlitwy oraz częstotliwość uczestnictwa we Mszy świętej pomiędzy duchowością pracowników a ich satysfakcją z pracy. Zastosowano następujące miary: Skalę Duchowości Pracowników, Skalę Wdzięczności wobec Organizacji, Skalę Zaufania do Przełożonego, Kwestionariusz Postrzeganego Stresu w Pracy oraz trzy jednopytaniowe miary dotyczące satysfakcji z pracy, częstotliwości 
pobytu na mszy świętej oraz częstotliwości modlitwy. Wdzięczność wobec organizacji pośredniczyła między duchowością pracowników a ich satysfakcją z pracy. Zaufanie do przełożonego było mediatorem między postawą wobec współpracowników a ich satysfakcją z pracy. Również stres pośredniczył między stosunkiem do Boga lub innej „Siły Wyższej” a satysfakcją z pracy. Potwierdzono moderacyjny efekt częstotliwości modlitwy oraz uczestnictwa we Mszy świętej pomiędzy stosunkiem do Boga lub innej „Siły Wyższej” i satysfakcją z pracy, jak również postawą wobec współpracowników i satysfakcją z pracy. Potwierdzono istotną rolę duchowości pracowników dla kształtowania ich satysfakcji z pracy. Zidentyfikowano mechanizmy pośredniego wpływu duchowości pracowników na ich satysfakcję z pracy poprzez wdzięczność wobec organizacji, zaufanie do przełożonego oraz stres.

Słowa kluczowe: duchowość pracowników, wdzięczność wobec organizacji, zaufanie do przełożonego, stres, satysfakcja z pracy.

DOI: 10.7862/rz.2018.mmr.59

Tekst ztożono do redakcji: listopad $2018 \mathrm{r}$.

Tekst przyjęto do druku: grudzień 2018 r. 
